\title{
RADIOGRAPHIC EVALUATION OF THORACOLUMBAR STABILIZATION USING TWO DIFFERENT ORTHOSIS SYSTEMS
}

\author{
AVALIAÇÃO RADIOGRÁFICA DA ESTABILIDADE DA TRANSIÇÃO TORACOLOMBAR UTILIZAN- \\ DO DOIS MODELOS DE ÓRTESES
}

\author{
EVALUACIÓN RADIOGRÁFICA DE LA ESTABILIDAD DE LA TRANSICIÓN TORACOLUMBAR \\ UTILIZANDO DOS MODELOS DE ÓRTESIS
}

\author{
Murilo Tavares Daher, ${ }^{1,2}$ Vinício Nunes Nascimento, ${ }^{2}$ Pedro Felisbino JR, ${ }^{2}$ Nilo Carrijo Melo, ${ }^{2}$ Brenda Cristina Ribeiro Araújo, ${ }^{2}$ Sérgio Daher ${ }^{2}$ \\ 1. School of Medicine of the Universidade Federal de Goiás (DOT/FM/UFG) - Goiás, GO. \\ 2. Centro de Reabilitação e Readaptação Dr. Henrique Santillo (CRER - Goiânia/GO) Goiânia/GO.
}

\begin{abstract}
Objective: To evaluate radiographically the stability of the thoracolumbar junction comparing the two types of thoracolumbosacral orthosis (TLSO) most used in our environment, the Jewett and the Boston braces. Methods: After approval by the institutional review board, nine participants were submitted to X-rays in the profile view, with the beam focused on T12, in the orthostatic position, maximal flexion without brace and maximal flexion with the Jewett and the Boston braces. The Cobb angle of the thoracolumbar junction (T10-L2) was measured and the values compared using the student $T$ test $(p<0.05)$. Results: The Boston brace promoted greater stabilization of the thoracolumbar junction during flexion of the trunk compared to the Jewett brace $(p<0.05)$. In addition, there was no statistical difference in the Cobb angle of the thoracolumbar junction in the orthostatic (neutral) position and in flexion using the Boston brace. Conclusion: The Boston brace presented greater stabilization of the thoracolumbar region during flexion of the trunk compared to the Jewett brace. Level of Evidence II; Prospective comparative study.
\end{abstract}

Keywords: Orthotic devices; Spinal injuries; Radiography; Treatment outcome.

\section{RESUMO}

Objetivo: Avaliar radiograficamente a estabilidade da transição toracolombar comparando os dois tipos de órteses toracolombosacras (OTLS) mais utilizadas em nosso meio: o colete de Jewett e o colete de Boston. Métodos: após aprovação do comitê de ética, nove participantes foram submetidos à radiografias em perfil, com raios centrados em T12 na posição ortostática, flexão máxima sem colete e flexão máxima com a órtese de Jewett e com a de Boston. Foi realizada a medida do angulo de Cobb da transição toracolombar (T10-L2) e os valores comparados utilizando o teste T de Student $(p<0,05)$. Resultados: O colete de Boston promoveu maior estabilização da transição toracolombar durante a flexão do tronco em relação ao colete de Jewett $(p<0,05)$. Além disso, não houve diferença estatística do angulo de Cobb da transição na posição ortostática (neutro) e na flexão utilizando o colete de Boston. Conclusão: O colete de Boston apresenta maior estabilização da região toracolombar durante a flexão do tronco em relação ao colete de Jewett. Nível de Evidência II; Estudo prospectivo comparativo.

Descritores: Aparelhos ortopédicos; Traumatismos da coluna vertebral; Radiografia; Resultado do tratamento.

\section{RESUMEN}

Objetivo: Evaluar radiográficamente la estabilidad de la transición toracolumbar comparando los dos tipos de órtesis toracolumbosacras (OTLS) más utilizadas en nuestro medio, corsé de Jewett y corsé de Boston. Métodos: Después de la aprobación del comité de ética, nueve participantes fueron sometidos a radiografías laterales con radios centrados en T12 en posición ortostática, con flexión máxima sin y con corsé de Jewett y de Boston. Se llevó a cabo la medida del ángulo de Cobb de la transición toracolumbar (T10-L2) y los valores se compararon con la prueba t de Student $(p<0,05)$. Resultados: El corsé de Boston produjo mayor estabilización de la transición toracolumbar durante la flexión del tronco con respecto al corsé de Jewett $(p<0,05)$. Además, no hubo diferencia estadística en el ángulo de Cobb de la transición en la posición ortostática (neutra) y en flexión con el corsé de Boston. Conclusiones: El corsé de Boston proporciona mayor estabilización de la región toracolumbar durante la flexión del tronco con relación al corsé de Jewett. Nivel de evidencia II; Estudio prospectivo comparativo.

Descriptores: Aparatos ortopédicos; Traumatismos vertebrales; Radiografía; Resultado del tratamiento.

\section{INTRODUCTION}

The thoracolumbar junction (T10-L2) is the region most prone to thoracic and lumbar spine fractures ${ }^{1}$ and the treatment of these fractures is still controversial.
Although used for several centuries since the time of Hippocrates, ${ }^{2}$ the conservative treatment of transitional fractures was only systematically described by Bedbrook ${ }^{3}$ in the 1970s, when bed rest was recommended for 6 to 8 weeks, followed by gradual mobilization. 
Thoracic Lumbar Sacral Orthoses (TLSO) became popular in the 1980s, and several authors reported good results with this approach in the treatment of burst fractures. ${ }^{4,5}$

The good results of conservative treatment were confirmed in the 1990s, and some authors began to advocate earlier patient mobilization. ${ }^{6,7}$ At the same time, there was growing enthusiasm for the surgical approach, seeking a more anatomical reduction of the fracture in an attempt to achieve better clinical results. However, Wood et al., in a prospective, randomized study in the early 2000 s, demonstrated that patients with burst fracture without neurologic deficit presented better results with conservative treatment (orthoses) when compared to surgical treatment.

More recently, a number of authors have proposed an even less invasive approach, questioning the use of the brace in more stable thoracolumbar spine injuries. ${ }^{9,10}$ However, the use of orthoses for the conservative treatment of thoracolumbar junction fractures is still common practice in our field, and there is no consensus regarding the best brace to be used.

The aim of this study is to perform a radiographic evaluation of the stability of the thoracolumbar junction, comparing the two types of TLSO used most often in our specialty, the Jewett brace, and the Boston brace.

\section{METHODS}

Following approval by the Institutional Review Board (IRB) (50271015.1.0000.0023) we selected nine healthy male volunteers with no history of spinal pathologies. These volunteers, who were all employees or physicians of the institution where the research study was conducted, filled out an informed consent form.

All the participants were taken to the orthopedic workshop (which is licensed to operate by the Brazilian Ministry of Health under ministerial directive No. 793 of April 24, 2012) where two types of custom-made TLSO were produced:

Jewett: orthosis in hyperextension with support in the anterior region of the sternum and pubis, and posterior support at the thoracolumbar junction. ${ }^{11}$ (Figure 1 )

Boston: custom made orthosis in rigid polypropylene (Figure 2)

These models were chosen because they are the most used in our field for the treatment of thoracolumbar junction fractures. ${ }^{11}$

Once the braces had been produced, the research subjects underwent spine $x$-rays with the central beam targeted on T12, in the lateral view, in the neutral orthostatic position, in maximum flexion without brace, and in maximum flexion with the Jewett and Boston braces. Prior to the tests in flexion, the participants were instructed to perform five cycles of flexion and extension of the trunk to familiarize themselves with movement wearing the brace. All the tests were supervised and positioned by one of the authors of the work (VNN) to ensure correct positioning of the patient, uniformity of the test, and correct adjustment of the braces. The tests were performed

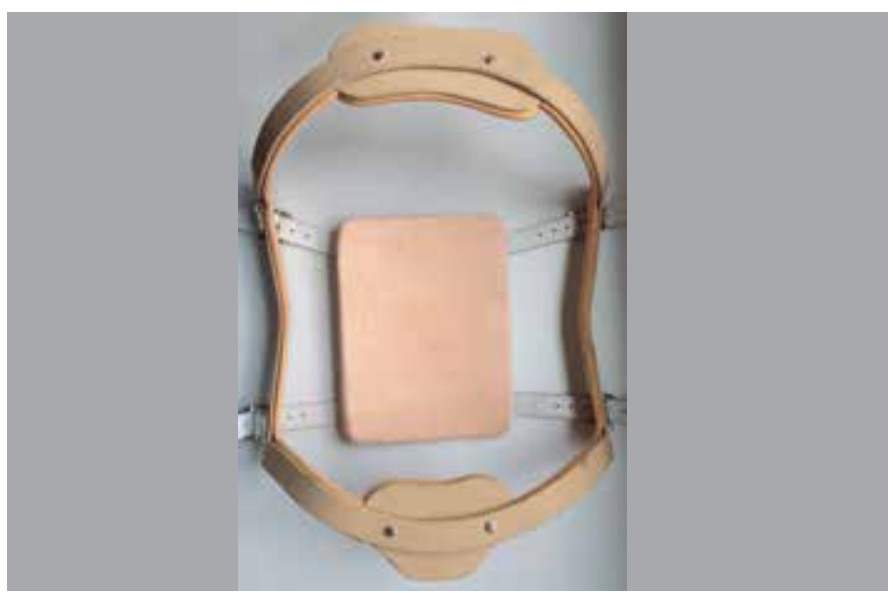

Figure 1. Jewett Brace.

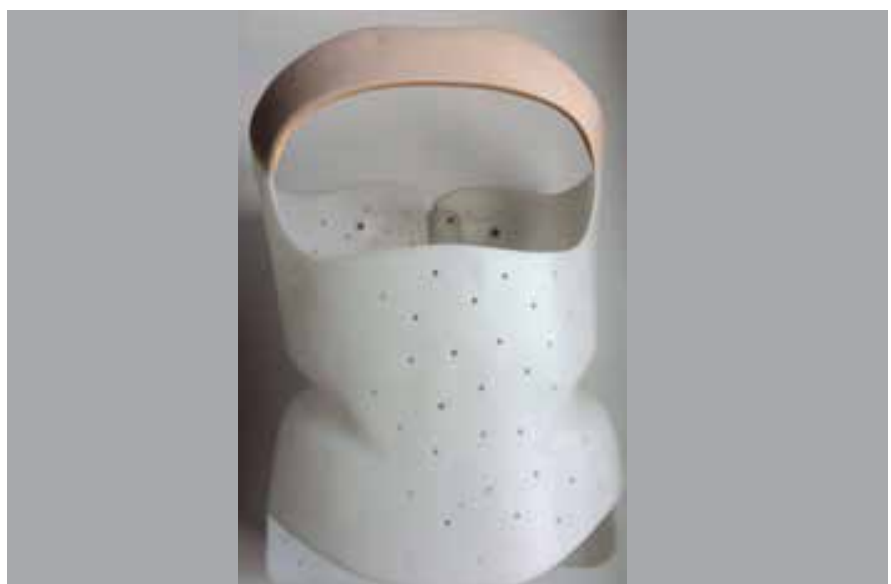

Figure 2. Boston Brace.

at a constant distance of $1.8 \mathrm{~m}$ using Polymat Plus radiography equipment (Siemens Medical System, Inc, Iselin, NJ) and scanned in CR (Computed Radiography, Fujifilm Medical Systems, USA). Lead protective garments were worn in the area of the thyroid and gonads, and goggles were also worn

The Cobb angle of the thoracolumbar junction (upper plateau of T10 and lower plateau of L2) was measured, and the values were compared with the patient in the orthostatic position without a brace, in flexion without a brace, and in flexion wearing either the Jewett brace or the Boston brace. Extension radiographs were not taken, in order to minimize exposure to radiation, as the main function of the orthosis is to avoid kyphotic deformities.

In addition, all the participants were asked the following questions: Which brace gave you a sense of greater stability? Which brace did you feel most comfortable wearing?

The data were collected and recorded in a spreadsheet (Excel Microsoft Office 2013) and subsequently transferred to SPSS - IBM software version 23 for statistical analysis. Quantitative variables were presented with their means and standard deviations. Comparison of means was performed using the paired sample t-test. All tests were applied accepting a 5\% probability of error and considering a 95\% confidence interval.

\section{RESULTS}

The study participants were 9 volunteers with an average age of 28.8 years $( \pm 2.1)$ and mean Body Mass Index of $26.5 \mathrm{Kg} / \mathrm{m}^{2}( \pm 3.0)$.

The Cobb angles are described in Table 1.

There was no association between mobility of the thoracolumbar junction and BMI using either brace.

Comparison of thoracolumbar junction angulation is described in Table 2. Kyphotization with the Boston brace was significantly lower than that permitted with the Jewett brace. In addition, there was no statistical difference between the neutral position and wearing the Boston brace.

All participants reported that the Boston brace gave them a sense of greater stability, except for one who was indifferent. In addition, 7 participants said that the Jewett brace was more comfortable, although one participant said there was no difference, and one found the Boston brace more comfortable.

Table 1. Cobb angles of the thoracolumbar junction (T10-L2).

\begin{tabular}{c|c}
\hline Evaluation & Mean (Standard Deviation) \\
\hline Neutral orthostatic & $7.0^{\circ}(5.7)$ \\
\hline Maximum flexion without brace & $28.0^{\circ}(6.1)$ \\
\hline Flexion with Boston & $7.9^{\circ}(6.5)$ \\
\hline Flexion with Jewett & $12.3^{\circ}(7.4)$ \\
\hline
\end{tabular}


Table 2. Comparison of the degree of kyphosis with and without the use of the braces.

\begin{tabular}{c|c|c}
\hline Evaluation & $\begin{array}{c}\text { Mean (Standard } \\
\text { Deviation) }\end{array}$ & $\mathbf{p}$ \\
\hline Flexion with Boston & $7.9^{\circ}(6.5)$ & $0.021^{*}$ \\
\hline Flexion with Jewett & $12.3^{\circ}(7.4)$ & \\
\hline Maximum flexion without brace & $28.0^{\circ}(6.1)$ & $<0.001^{*}$ \\
\hline Flexion with Boston & $7.9^{\circ}(6.5)$ & \\
\hline Maximum flexion without brace & $28.0^{\circ}(6.1)$ & $<0.001^{*}$ \\
\hline Flexion with Jewett & $12.3^{\circ}(7.4)$ & \\
\hline Orthostatic in neutral position & $7.0^{\circ}(5.7)$ & $0.626^{*}$ \\
\hline Flexion with Boston & $7.9^{\circ}(6.5)$ & \\
\hline Orthostatic in neutral position & $7.0^{\circ}(5.7)$ & $0.044^{*}$ \\
\hline Flexion with Jewett & $12.3^{\circ}(7.4)$ & \\
\hline *Studentt test for paird samper. & &
\end{tabular}

\section{DISCUSSION}

Adequate treatment of thoracolumbar junction fractures is still a controversial issue. Although there are more recent studies showing that some fractures can be treated with early ambulation and without a brace, this practice is not yet the most common. ${ }^{9,10}$

In the study by Bailey et al., ${ }^{9}$ only patients with burst fractures with segmental kyphosis below $35^{\circ}$ were included in the sample. The patients were randomized to wear the brace or not, and the clinical and radiographic results were compared. Although the main evaluation, performed at 3 months of follow-up, did not show any functional difference between the groups, in the earlier evaluation the group that wore the brace experienced less pain and less kyphosis of the segment, but did not achieve statistical significance. In addition, this study used post-cast orthoses, with a design similar to that of the Jewett brace, which was the orthosis with the least ability to stabilize the thoracolumbar segment in our study.

The study by Ohana et al. $^{10}$ is a retrospective cohort study that assessed patients treated with and without a brace. Although the lack of a standard indication of brace usage was mentioned, non-use of orthosis in fractures with a more stable aspect (initial kyphosis of $9.7^{\circ}$ in the group treated with a brace and $5.7^{\circ}$ in the group treated without a brace, with no statistical difference) is usually recommended. Only wedge fractures (type A1 according to the $\mathrm{AO}$ classification), ${ }^{12}$ which are very stable fractures, in which brace stabilization may lose its function, were treated. Moreover, the assessment was only radiographic after one year of follow-up, not allowing evaluation of the potential pain relieving action of the brace in the early phase of the treatment.

In view of all these factors, use of the brace is still a very common practice in the treatment of patients with thoracolumbar junction fractures. Despite several reports of good results, 5,6 little is known about the best orthesis to be used at this time.

The Jewett or hyperextension orthesis is one of the most used. Although American literature predominantly uses prefabricated and adjustable orthoses, in our field this is not the most common practice due to the high cost of these devices.

Our study demonstrated that the Boston brace provides greater stabilization of the thoracolumbar junction during flexion than the Jewett brace. It has also been shown that even during forced flexion with the Boston brace, there is no kyphotization of this region in relation to the neutral position, which did not happen during flexion with the Jewett brace.

These results suggest that the Boston brace is a better treatment option for thoracolumbar spine fractures than the Jewett brace, especially in cases requiring greater stability (e.g., burst fractures with a lower degree of kyphotization than necessary for surgical indication).

Our study has several limitations, such as sample size and evaluation of the intact region (without the presence of a fracture). However, it was the only study found in the literature that assessed the radiographic mobility of the region most affected by fractures, comparing the two main types of orthosis used in our field.

\section{CONCLUSION}

The Boston brace provides greater stabilization of the thoracolumbar region during flexion of the trunk than the Jewett brace.

All authors declare no potential conflict of interest related to this article.

CONTRIBUTION OF THE AUTHORS: Each author made significant individual contributions to this manuscript. The author MTD (0000-0001-9589$5596)^{\star}$ conceived the study and contributed to the manuscript. VNN $(0000-0002-5280-8146)^{\star}$ wrote and also prepared the manuscript. The authors NCM $(0000-0003-3879-6991)^{*}$ and PFJ (0000-0003-3952-8470)* assisted in the data collection. The author BCRA (0000-0003-3875-8557)* is monitor of the trial site of the group and assisted in the bibliographic review. The author SD (0000-0002-0078-9924)* is the senior physician of the group and assisted in the idea, as well as in the drafting of the manuscript. ${ }^{*} \mathrm{ORCID}$ (Open Researcher and Contributor ID).

\section{REFERENCES}

1. Holmes JF, Miller PQ, Panacek EA, Lin S, Horne NS, Mower WR. Epidemiology of thoracolumbar spine injury in blunt trauma. Acad Emerg Med. 2001;8(9):866-72.

2. Bradford DS, Akbarnia BA, Winter RB, Seljeskog EL. Surgical stabilization of fractures and fracture dislocations of the thoracic spine. Spine 1977;2:185-96.

3. Bedbrook GM. Treatment of thoracolumbar dislocation and fractures with paraplegia. Clin Orthop Relat Res. 1975;(112):27-43.

4. Denis F, Armstrong GW, Searls K, Matta L. Acute thoracolumbar burst fractures in the absence of neurologic deficit. A comparison between operative and nonoperative treatment. Clin Orthop Relat Res. 1984;(189):142-9.

5. Reid DC, Hu R, Davis LA, Saboe LA. The nonoperative treatment of burst fractures of the thoracolumbar junction. J Trauma. 1988;28(8):1188-94.

6. Cantor JB, Lebwohl NH, Garvey T, Eismont FJ. Nonoperative management of stable thoracolumbar burst fractures with early ambulation and bracing. Spine (Phila Pa 1976). 1993;18(8):971-6

7. Chow GH, Nelson BJ, Gebhard JS, Brugman JL, Brown CW, Donaldson DH. Functional outcome of thoracolumbar burst fractures managed with hyperextension casting or bracing and early mobilization. Spine (Phila Pa 1976). 1996;21(18):2170-5
8. Wood K, Buttermann G, Mehbod A, GarveyT, Jhanjee R, Sechriest V. Operative compared with nonoperative treatment of a thoracolumbar burst fracture without neurological deficit. A prospective, randomized study. J Bone Joint Surg Am. 2003;85-A(5):773-81.

9. Bailey CS, Dvorak MF, Thomas KC, Boyd MC, Paquett S, Kwon BK, et al. Comparison of thoracolumbosacral orthosis and no orthosis for the treatment of thoracolumbar burst fractures: interim analysis of a multicenter randomized clinical equivalence trial. J Neurosurg Spine. 2009;11(3):295-303.

10. Ohana N, Sheinis $D$, Rath E, Sasson A, Atar D. Is there a need for lumbar orthosis in mild compression fractures of the thoracolumbar spine?: A retrospective study comparing the radiographic results between early ambulation with and without lumbar orthosis. J Spinal Disord. 2000;13(4):305-8.

11. Patwardhan AG, Li SP, Gavin T, Lorenz M, Meade KP, Zindrick M. Orthotic stabilization of thoracolumbar injuries. A biomechanical analysis of the Jewett hyperextension orthosis. Spine (Phila Pa 1976). 1990;15(7):654-61.

12. Vaccaro AR, Oner C, Kepler CK, Dvorak M, Schnake K, Bellabarba C, et al. AOSpine thoracolumbar spine injury classification system: fracture description, neurological status, and key modifiers. Spine (Phila Pa 1976). 2013;38(23):2028-37. 